\title{
How Effective Is the Monetary Policy on the Real Sector in Nigeria?
}

\author{
Ebenezer O. Oladimeji ${ }^{1}$, Ebenezer Bowale ${ }^{1} \&$ Henry Okodua ${ }^{1}$ \\ ${ }^{1}$ Department of Economics and Development Studies, Covenant University, Ota, Nigeria \\ Correspondence: Ebenezer O. Oladimeji, Department of Economics and Development Studies, Covenant University, \\ Ota, Nigeria. Tel: 234-81-3343-8299. E-mail: ebonyseyai@yahoo.com
}

Received: July 9, 2020

doi:10.5430/rwe.v11n5p388
Accepted: August 13, 2020

Online Published: September 14, 2020

URL: https://doi.org/10.5430/rwe.v11n5p388

\begin{abstract}
In the past few years, the real sector became an area of interest in scholarly and public intellectual discuss, towards a sustainable performance of the Nigerian economy. Successive governments also realized the need to diversify the economy from high dependence on oil into deepening the real sector, through monetary policy that allows more credit flow to the real sector. In a quest to reconcile the current state of the Nigerian real sector with the renewed efforts of the government and the monetary authority to revamp the sector, this study investigated the effectiveness of this process and reexamined the transmission channels, using a structural vector autoregressive econometric approach (SVAR). The results showed that the credit channel and asset price channel are the dominant monetary policy transmission channels to the real sector. However, there was a significant effect on the effectiveness of the transmission process, when credit risk was added to the model, as it revealed vital information about the behaviour of the banking system in response to monetary policy actions of the monetary authority, during the period of high credit risk/default risk. This study, therefore, recommends that monetary authorities should always consider the credit preference of the banking system and the order of transmission channels, before embarking on any monetary policy aimed at stimulating the real sector and other sectors of the economy.
\end{abstract}

Keywords: monetary policy, real sector, transmission channels, credit risk, Structural VAR (SVAR)

\section{Introduction}

The real sector is among the vital sectors of major economies of the world (Adeusi and Aluko, 2015). It is the productive sector of an economy, where goods and services are produced for consumption by various economic agents. It also creates employment opportunities and contributes to the growth and development of a nation. As a result of these contributions to the wellbeing of the citizens, government across most economies of the world have always been deliberate to grow the sector, through fiscal and monetary policies. This is essentially to align with their macroeconomic objectives (Falade and Folorunso, 2015; Jelilov and Musa, 2016). In the past few years in Nigeria, the government and the monetary authority realized the need to diversify the economy from oil to deepening the real sector. This brought about a renewed emphasis and economic strategy to use the instruments of monetary and fiscal policies to improve the sector. A number of empirical studies have been carried out by scholars to examine the impacts of these policies on the real sector (Ajayi and Aluko, 2017; Oboh, 2017; Okorie, Manu and Simon-Peter, 2017; and Adegoriola, 2018). However, the question that is still very opened in the literature and also requires further investigation is, 'how effective are these policies?' From the monetary policy angle, which is the focus of this study, Ndekwu (2013) in his study, established that except the monetary authorities properly understand the channels through which their policy actions transmit to the real sector, the monetary policy cannot be effective. Scholars have also done extensive studies in this area. A few of these studies in Nigeria are the research work of Obafemi and Ifere (2015) and Osundina, Tella and Adesoye (2018) who found interest rate channel as the strongest channel of monetary policy to the real sector. Some found exchange rate channel as the strongest (Adekunle, Baba, Stephen, Ogbuehi, Idris and Zivoshiya, 2018); some found asset price channel as the strongest and others found credit channel as the strongest (Emenike, 2017; Asaleye, Popoola, Lawal, Ogundipe and Ezenwoke, 2018). Therefore, there is no clear consensus among the authors till date as to the main channel of monetary policy transmission to the Nigerian real sector.

The financial and banking system play a crucial role in all these transmission processes. Without proper understanding of the variables that determine the behavioural lending pattern of the deposit money banks to the real sector, the monetary authority may not be able to predictably forecast the reactions of the banking system and real 
sector to any real sector targeted policy. Credit risk is one of such variables that has been neglected both in theory and previous empirical studies. This risk is associated with the failure of the borrower of funds to pay back their loan credit (Kargi, 2011; Hassan and Mohamed; 2007). If the credit risk of loan to real sector is high, the banking system will not channel the expected credit/funds to the sector. This risk affects banks' profitability, performance, and solvency. As a result, banks reduce credit to the real sector, when the risk of default is high. Even in a period of high liquidity in the banking system in response to expansionary monetary policy, banks prefer to invest in low risk government securities to secure their funds as against lending to the real sector, if the credit risk is high. This makes it challenging for the monetary authority to influence the banking system to transmit funds to the real sector. This is the case in Nigeria today, as the central bank of Nigeria in recent past seems to be finding it challenging to influence the deposit money banks to channel liquidity/credit to the real sector. The evidence to this is the statement by the CBN governor, Godwin Emefile, in June, 2019, of the decision of the CBN to limit deposit money banks' unlimited access to government securities to redirect their lending focus to the private sector, as they abandon their key roles of stimulating growth by investing in government instrument, beyond regulatory threshold.

Also in the circular dated July 03, 2019 (CBN Circular July 03, 2019), the CBN increased the minimum loan to deposit ratio (LDR) of the deposit money banks from $58.5 \%$ to $60 \%$. This is majorly to improve lending to the real sector. In this circular, any bank that fails to meet this minimum LDR shall pay a penalty of additional cash reserve requirement equal to $50 \%$ of the lending shortfall of the target LDR. It is important to note that the minimum LDR before the new circular was $58.5 \%$, while the maximum was $80 \%$. Since the maximum lending rate is usually higher than the interest from government risk-free securities, one would have expected the deposit money banks to increase their LDR to $80 \%$, without been compelled by the CBN. This may not be the case if the default risk is high. The banks will rather want to maintain the regulatory minimum threshold or below. On July 10, 2019, the CBN published another circular where the standing deposit facility (SDF) was reduced from N7.5billion to N2billion (CBN Circular July 10, 2019). This means that any deposit to CBN by banks in excess of N2billion will not attract any interest. The SDF is a regulatory window with an option for banks to deposit their excess funds, for which there are no takers in the money market. The interest is usually below the monetary policy rate. In 2014, it was observed by the CBN that banks had preference for keeping their idle funds at the central bank, which the CBN considered as constraining the process of financial intermediation. In order to encourage the banks to increase lending to the productive sector of the economy, the CBN reduced the SDF to N7.5billion (CBN Circular November, 2014).

However, this preference continued to increase, as banks still prefer to earn little interest from keeping their idle funds with the CBN as against lending to a perceived risky sector. It was in response to this that made the CBN to further reduce the SDF to N2billion (CBN Circular July 10, 2019) with the intention to increase lending to the real sector and discourage the banks from depositing their idle funds with the CBN. The implication of this is that the SDF window is now being used by banks to secure their funds if the probability of getting investors to pay back the borrowed fund is low, as a result of high credit risk. Hence, high credit risk is one of the main reasons why deposit money banks sometimes cut their lending to the real sector as they prefer not to earn interest on loan to losing their capital, through accumulation of non-performing loans. The effectiveness of momentary policy actions to channel liquidity to the real sector may be hindered by credit risk. This is an area that has not been critically examined by previous studies. Therefore, the study considered credit risk in the model and examined the extent of impact on the effectiveness of monetary policy on the real sector. The findings of the study revealed that, in the period of high credit risk, the asset price channel is the most effective transmission of monetary policy to the real sector in Nigeria and the credit channel is less effective. The study is divided into six sections, beginning from introduction. Section two presents relevant literature to the study; section three highlights the methodology and data, while section four details the results and discussions. The conclusion and recommendations are respectively in section five and six.

\section{Literature Review}

Monetary policy is a deliberate action of the monetary authorities to influence the quantity, cost, and availability of money credit in order to achieve desired macroeconomic objectives of internal and external balances (CBN, 2011). With this action, the money supply and/or interest rate are affected, which in turns affect the nominal and real macroeconomic variables, depending on macroeconomic swings. The effects of the policy actions pass through a number of channels, which include interest rate, asset price, exchange rate and credit channels (Mishkin, 1996). In Nigeria, previous studies have examined the effects and transmission channels of monetary policy to the real sector, but no study to the best of author's knowledge has considered credit risk as a vital variable in the monetary policy transmission process. Using vector autoregression and autoregressive distributed lag models, Uduak and Obasi (2018) studied the monetary policy pass-through in Nigeria. The results of their study revealed that monetary policy has no long-run relationship with economic activity and credit channel was not effectual in the transmission of monetary 
policy, while money supply, exchange rate, and interest rate channels were positive channels of monetary policy transmission. However, the findings that credit channel was not effectual in the transmission of monetary policy is doubtful and in contrast to the credit channel dominance in Nigeria, as revealed by Emenike (2017), Asaleye et al. (2018). The omission of the short term lending rates in the model may be a specification error that was responsible for this. The official interest rate alone (monetary policy rate) may not fully explain the transmission of monetary impulses to the real sector. If the monetary policy rate is held stable for a longer period, the activities of the central bank in the open market can have effect on bank reserves, short term interest rates and credit to the real sector.

Using the johansen cointegration test and error correction mechanism approach, Iortyer, Imoisi and Abuh (2017) studied the interest rate and the behaviour of the Nigerian economy. The variables considered in the model were credit to private sector, domestic interest rate, gross domestic product and credit to government. According to the research outcomes, interest rate, credit to the government and credit to the private sector significantly impacted on economic performance. However, Iortyer et al. (2017) only used credit to government, credit to private sector and domestic interest rate to determine the gross domestic product, which was used as a proxy for economic activity. The gross domestic product is a macroeconomic variable which is determined by a number of variables. For instance, other variables such as money supply, external reserve, exchange rate, fixed capital formation and degree of openness affect gross domestic product. The error terms of the included explanatory variables may reflect a systematic pattern of these omitted variables, but unfortunately Iortyer et al. (2017) never carried out a second order econometric tests to ascertain the reliability of the estimates of the parameters in the model.

Ebire and Ogunyinka (2018) examined the existence of bank lending channel of monetary policy transmission in Nigeria. Using vector error correction mechanism, the variables the authors included in their model were loans to private sectors, real gross domestic product, bank capital, lending rate, borrowing rate and bank capital. The authors discovered the presence of three cointegration relationship among the variables, while testing for exclusion and exogeneity restrictions on the cointegration relationships. Their results further revealed a significant and positive relationship between loan supply and borrowing rate; the relationship with the lending rate was negatively insignificant, revealing the existence of a lending channel of monetary policy transmission. Relying on these results Ebire and Ogunyinka (2018) recommended that more attention should be given to credit rates by the CBN when embarking on monetary policy decisions. However, the authors' claim of the novelty of their study as the first to consider the bank lending channel in Nigeria is questionable. They cited only Olowofeso, Bada, Bassey \& Dzaan (2014) as evidence that previous studies in Nigeria concentrated on banks' balance sheet channel. This is not convincing enough, as authors such as Omorokunwa and Adegboye (2011) and Matousek and Solomon (2017) had also investigated bank lending channel of monetary policy transmission in Nigeria.

Ogolo and Tamunotonye (2018) investigated the effect of monetary policy on commercial bank lending to the real sector of the Nigerian economy. They used two multiple regressions to model the commercial banks' lending to both the agricultural and manufacturing sectors. The regression results of the first model showed that monetary policy rate and interest rate had a positive relationship with commercial banks' lending to the agricultural sector, but the treasury bill rate, exchange rate, liquidity ratio, and broad money supply had a negative effect. The results of the second model indicated that exchange rate, interest rate, broad money supply, treasury bill rate and liquidity ratio had a negative effect on commercial banks' lending to the manufacturing sector, while monetary policy rate had a positive relationship. However, these models did not fully capture the objective of the study, as only the manufacturing and agricultural sectors were used as proxies for the real sector, leaving out the remaining construction, trade, and services. Multiple regression model may not also give a robust result in the relationship. Other area of concern is using money supply as explanatory variable to determine credit to the real sector. This is because credit to the real sector can equally cause changes in the money supply. For instance, when credit is advanced to the real sector, it expands demand deposit, which leads to an increase in the money supply. So, it would have been a better option for Ogolo and Tamunotonye (2018) to use a simultaneous equation econometric technique, as against a single equation technique.

Sima (2018) carried out a study on the effects of monetary policy shocks on the real economy in Iran, using both the traditional vector autoregression model and factor vector autoregressive approach. The variables included in his study were investment, gross domestic product, government consumption, private consumption, capacity utilization, money base, broad money supply, consumer price index, oil price index and exchange rate. While comparing the results from these two econometric techniques, Sima (2018) found a factor vector autoregressive approach to be consistent with theory and better than the standard vector autoregressive model which showed evidence of liquidity and prize puzzles. In response to a contractionary monetary policy shocks, it was established that exchange rate increased, gross domestic product decreased consistently up to the third quarter, after which the impact became zero. 
According to author's findings, the real output responded negatively to money base shocks. However, the author never found out why an increase in money base led to a decrease in the real output; the effect of credit risk may have accounted for this. This is because, any monetary policy that increases the money base, leads to an increase in reserves, which consequently increases the liquidity in the banking system. If credit risk is low and banks have a strong level of assurance of getting real investors to repay any loans advanced to them, they will give out more credits, otherwise cut down on loans. If the author had considered credit risk variable in his model, the research result may have been more robust.

Forhad, Homaifar and Salimullah (2017) examined the monetary policy transmission effect on Bangladesh's real economy. Using a structural vector autoregressive model, they considered variables such as broad money supply, real gross domestic product, consumer price index, interest rate and real effective exchange rate. The study showed that the monetary policy was slightly effective in the short run to affect the output, price level, and exchange rate, though Bangladesh monetary policy relied on the interest rate targeting. They established monetary policy as an important source of fluctuations in the real output and price level in Bangladesh. However, the authors did not consider other transmission channels like asset price and bank lending channels. Hence, the results may not be a balanced analysis to also trace the effects of monetary policy through these omitted channels.

Erdogdu (2017) studied the functioning and effectiveness of the monetary transmission mechanism in Turkey, with the objective to identify which monetary channels are actively working. The author used a vector autoregressive model and included variables such as monthly interbank overnight simple weighted average interest rate, money supply, Central Bank buying exchange rate, total domestic banking sector Loans, consumer price index and national stock index. The research findings revealed that the interest rate channel of transmission worked actively in Turkey and the exchange rate channel never played a decisive role in output, though it had a significant effect on the general price level. It was further established that the asset price channel and the credit channel did not also work effectively. However, the author used the narrow money supply to represent the stock of money in the Turkish economy. This may not correctly capture the total money in circulation and Erdogdu (2017) did not justify in his study the reason for this choice of variable.

Comparing the monetary policy transmission in China with the United States, the Eurozone, and Japan, Lombardi, Siklos and Xie (2018) used standard vector autoregression and time-varying vector autoregressive model to examine the monetary policy transmission in these countries. The authors were interested in the interaction of monetary policy in China with the United States, Eurozone, and Japan; whether shocks from abroad influence the People's Bank of China's monetary policy. Lombardi et al. (2018) established a similar impact of monetary policy across the four economies, although the evolution of financial factors differed across these countries. The difference in the transmission mechanism that was discovered in China, the United States, and the Eurozone was attributed to the behaviour of the financial factor. Their findings further revealed evidence of interdependence, as global factors were seen as having the biggest impact on the Chinese economy, while the effect on Japan's economy was the smallest. The authors concluded that the Chinese economy has also become important as the three large economies that were considered. However, Lombardi et al. (2018) focused on the interest rate channel and the financial market.

Mahathanaseth and Tauer (2019) used a random-effects panel data approach to investigate on monetary policy transmission through the bank lending channel in Thailand. The authors' main objective was to investigate the strength of the bank lending channel in the transmission of monetary policy, using a data set covering ten deposit money banks in Thailand. As against the aggregate banking data, the individual bank's balance sheet was used to estimate the total supply and demand for loanable funds. The results revealed a complete pass-through from the monetary policy rate to the interbank rate, meaning a perfect substitute between the central bank and interbank loans. The pass-through from the policy rate to loan deposit rates was incomplete, while the interbank rate was an effective target rate. The impact of the policy rate on bank retail rate was sluggish, which the authors attributed to market imperfections and financial frictions in the Thai economy. The monetary tightening in the long run made banks to curtail their loan supply and demand for interbank borrowing. In summary, interest channel and credit are operational. Although Mahathanaseth and Tauer (2019) recognized that a disaggregated loan into various types such as consumption, investment, agriculture and housing may reveal additional information about each component response to monetary policy, considering credit risk may also reveal information about the pattern of responsiveness, especially in the area of credit for investment.

Paul (2019) assessed how monetary policy jointly affects the real economy and asset prices in the United States, using an estimator high-frequency surprises as a proxy for the structural monetary policy shocks. The proxy was used as an exogenous variable in the vector autoregressive model. While allowing for time-varying model 
parameters and comparing the response of house prices, stock and output to a monetary policy shock, the author discovered that the reactions of house prices and stock were low before 2007 to 2009 financial crises. The findings showed that economic activities and asset prices decrease in response to a tightening monetary policy, as they were not constant over time; stock and house prices exhibit substantial time variation in their response to monetary policy shocks and there was a co-movement between the level of house prices and the response of house prices. When house prices were high, they were less responsive to monetary policy shocks, but more responsive when prices were low. However, the result of the author was based on identified responses to unanticipated deviations of monetary policy from the reaction function. Paul (2019)'s analysis could not resolve the question of whether monetary policy should incorporate asset prices into its reaction function and how this could affect agents' economic decisions.

Aikman, Lehnert, Liang and Modugno (2017) examined the connectivity among financial conditions, credit and monetary policy transmission in the the United States. A threshold vector autoregressive model, which allows for nonlinear dynamics was used. The results showed that whenever credit went below its trend, a shock to financial conditions resulted in improved economic performance and monetary policy works expected, but when credit went above trend, a similar shock resulted in economic expansion in the near term and a recession in a later time. Also, when credit was above trend a tighter monetary policy did not lead to tighter financial conditions and ineffective in slowing down the economy. This means that the credit to gross domestic product gap played a vital role in the effectiveness of monetary policy and response of financial conditions to monetary impulses. Economic activities were improved by positive impulses to financial conditions, which also sustained expansion when the credit gap was low. When the credit gap was high, positive impulses to financial conditions eventually led to excess borrowing and economic contractions, although it stimulated economic activities in the short run. This means the effectiveness of monetary policy depends on the credit gap. However, when credit goes below its trend in the developing economy, a monetary shock to financial conditions may not significantly improve economic performance if the risk of loan default is high. Also, the authors failed to consider the period of the global financial crisis, where advanced economies like the United States sometimes result in quantitative easing, when the conventional monetary policy may not achieve the expected result. A question that begs for answers is whether the findings of the authors will still hold during this economic event.

Ahiawodzi and Sackey (2013) investigated the reasons for the credit rationing behaviour of deposit money banks to the private sector in Ghana. Even when interest rates were liberalized as a way of ensuring credit allocation, the banks still exhibited credit rationing behaviour. They found out that one of the major factors banks consider in determining how they allocate their funds to economic agents is credit risk. They recommended that the government should play an active role in the financial sector, while banks should fortify their loan monitoring system to help minimize default rate.

Doriana (2015) assessed bank lending bahaviour during financial crisis, with the objective to establish whether an increase in credit risk, which is connected with non-performing loans can make banks reduce their lending to the private sector. The author considered 488 listed and unlisted banks in Italy for the period of 2007 to 2013. According to his result, there is a negative impact of credit risk on bank lending behaviour, regardless of listing status or non-listing status. According to Fainstein and Novikov (2011), banks become more vulnerable during stagnation and recession period, as credit risk increases as a result of increasing level of aggregate indebtedness by private investors.

\section{Methodology and Data}

A non-recursive Structural Vector Autoregressive (SVAR) econometric method is used to analyse the responsiveness of the real sector to monetary impulses and the channels through which these occur. This method has become increasing popular to providing a credible approach for determining interactions among variables and has produced a better result in analyzing monetary policy effects (CBN, November 2014). A seasonally adjusted quarterly data from the period of 2008Q1 to 2018Q4, using Census X-13, were used. These data were majorly sourced from CBN statistical bulletin. Real sector output (Xt), monetary policy rate (mpr), interest rate (i), exchange rate (er), asset price (ap), maximum lending rate, credit to real sector (crs) and money supply were the variables considered in the model. Diagnostic tests such as the stability, autocorrelation, normality and heteroscedasticity tests were conducted to achieve reliable research results.

\section{Model Specification and Identification - Considering Effects of Credit Risk}

The structural form of the structure of the economy is represented as: 


$$
\mathrm{A} y_{t}=\phi+\sum_{j=1}^{p} \psi_{j} y_{t-j}+\Gamma \varepsilon_{t}
$$

A is the coefficient matrix of vector of endogenous macroeconomic variable represented as $y_{t} . \phi$ is the vector of constants in the model; $\Gamma$ represents the contemporaneous response of the variables to the shocks. $\psi_{j}$ represents the coefficient matrix of the vector of lagged values of endogenous variables, where $\psi_{j}=1, \ldots, p$, while $y_{t}$ is a vector of macroeconomic variables. $\varepsilon_{t}$ is a vector of serially uncorrelated structural shocks that has zero mean and diagonal variance co-variance matrix that is time invariant. In other word, variance-covariance matrix is constant over time. $\mathrm{E}\left[\varepsilon_{t} \varepsilon_{t}^{\prime}\right]=\Omega$; where $\varepsilon_{t} \sim$ iid $N_{n}(0, \Omega)$. Which means that the random variables are independent, identically distributed, having the same distributions, but may be contemporaneously correlated. The implicit form of the structural equations is represented as:

$$
\begin{aligned}
& m p r_{t}=f\left(\begin{array}{l}
i_{t}, e r_{t}, a_{p t}, m l r_{t}, c r_{t}, c r s_{t}, m 2_{t}, x_{t}, m p r_{t-j}, i_{t-j}, e r_{t-j}, a_{p t-j}, \\
m l r_{t-j}, c r_{t-j}, c r s_{t-j}, m 2_{t-j}, x_{t-j}
\end{array}\right) \quad m l r_{t}=f\left(\begin{array}{l}
m p r_{t}, i_{t}, e r_{t}, a_{p t}, c r_{t}, c r s_{t}, m 2_{t}, x_{t}, m p r_{t-j}, i_{t-j}, e r_{t-j}, a_{p t-j}, \\
m l r_{t-j}, c r_{t-j}, c r s_{t-j}, m 2_{t-j}, x_{t-j}
\end{array}\right) \\
& i_{t}=f\left(\begin{array}{l}
m p r_{t}, e r_{t}, a_{p t}, m l r_{t}, c r_{t}, c r s_{t}, m 2_{t}, x_{t}, m p r_{t-j}, i_{t-j}, e r_{t-j}, a_{p t-j} \\
m l r_{t-j}, c r_{t-j}, c r s_{t-j}, m 2_{t-j}, x_{t-j}
\end{array}\right) \quad c r_{t}=f\left(\begin{array}{l}
m p r_{t}, i_{t}, e r_{t}, a_{p t}, m l r_{t}, c r s_{t}, m 2_{t}, x_{t}, m p r_{t-j}, i_{t-j}, e r_{t-j}, a_{p t-j}, \\
m l r_{t-j}, c r_{t-j}, c r s_{t-j}, m 2_{t-j}, x_{t-j}
\end{array}\right) \\
& e r_{t}=f\left(\begin{array}{l}
m p r_{t}, i_{t}, a_{p t}, m l r_{t}, c r, c r s_{t}, m 2_{t}, x_{t}, m p r_{t-j}, i_{t-j}, e r_{t-j}, a_{p t-j}, \\
m r_{t-j}, c r_{t-j}, c r s_{t-j}, m 2_{t-j}, x_{t-j}
\end{array}\right) \quad c r s_{t}=f\left(\begin{array}{l}
m p r_{t}, i_{t}, e r_{t}, a_{p t}, m l r_{t}, c r_{t}, m 2_{t}, x_{t}, m p r_{t-j}, i_{t-j}, e r_{t-j}, a_{p t-j}, \\
m l r_{t-j}, c r_{t-j}, c r s_{t-j}, m 2_{t-j}, x_{t-j}
\end{array}\right) \\
& a_{p t}=f\left(\begin{array}{l}
m p r_{t}, i_{t}, e r_{t}, m l r_{t}, c r \\
m l r_{t-j}, c r r_{t}, m 2_{t}, x_{t}, m p r_{t-j}, i_{t-j}, e r_{t-j}, m 2_{t-j}, x_{t-j}
\end{array}\right) \quad m 2_{t}=f\left(\begin{array}{l}
m p r_{t}, i_{t}, e r_{t}, a_{p t}, m l r_{t}, c r \\
m l r_{t}, c r s_{t}, x_{t}, m p r_{t-j}, i_{t-j}, e r_{t-j}, a_{p t-j}, \\
m r_{t-j}, c r r_{t-j}, c r s_{t-j}, m 2_{t-j}, x_{t-j}
\end{array}\right) \\
& x_{t}=f\left(\begin{array}{l}
m p r_{t}, i_{t}, e r_{t}, a_{p t}, m l r_{t}, c r_{t}, c r s_{t}, m 2_{t}, m p r_{t-j}, i_{t-j}, e r_{t-j}, a_{p t-j}, \\
m l r_{t-j}, c r_{t-j}, c r s_{t-j}, m 2_{t-j}, x_{t-j}
\end{array}\right)
\end{aligned}
$$

Each endogenous variable, in each of the equations, is a function of all other endogenous variables and lag values of all the endogenous variables in the model. The explicit form of the equations is represented below:

$$
\begin{aligned}
& m p r_{t}=\phi_{10}-i_{t}-e r_{t}-a_{p t}-m l r_{t}-c r_{t}-c r s_{t}-m 2_{t}-x_{t}+\sum_{t-j}^{p} \psi_{11} m p r_{t-j}+\sum_{t-j}^{p} \psi_{12} i_{t-j} \\
& +\sum_{t-j}^{p} \psi_{13} e r_{t-j}+\sum_{t-j}^{p} \psi_{14} a_{p t-j}+\sum_{t-j}^{p} \psi_{15} m l r_{t-j}+\sum_{t-j}^{p} \psi_{16} c r_{t-j}+\sum_{t-j}^{p} \psi_{17} c r s_{t-j}+\sum_{t-j}^{p} \psi_{18} m 2_{t-j} \\
& +\sum_{t-j}^{p} \psi_{19} x_{t-j}+\varepsilon_{t}^{m p r_{t}}
\end{aligned}
$$




$$
\begin{aligned}
& i_{t}=\phi_{20}-m p r_{t}-e r_{t}-a_{p t}-m l r_{t}-c r_{t}-c r s_{t}-m 2_{t}-x_{t}+\sum_{t-j}^{p} \psi_{21} m p r_{t-j}+\sum_{t-j}^{p} \psi_{22} i_{t-j} \\
& +\sum_{t-j}^{p} \psi_{23} e r_{t-j}+\sum_{t-j}^{p} \psi_{24} a_{p t-j}+\sum_{t-j}^{p} \psi_{25} m l r_{t-j}+\sum_{t-j}^{p} \psi_{26} c r_{t-j}+\sum_{t-j}^{p} \psi_{27} c r s_{t-j}+\sum_{t-j}^{p} \psi_{28} m 2_{t-j} \\
& +\sum_{t-j}^{p} \psi_{29} x_{t-j}+\varepsilon_{t}^{i_{t}} \\
& e r_{t}=\phi_{30}-m p r_{t}-i_{t}-a_{p t}-m l r_{t}-c r_{t}-c r s_{t}-m 2_{t}-x_{t}+\sum_{t-j}^{p} \psi_{31} m p r_{t-j}+\sum_{t-j}^{p} \psi_{32} i_{t-j} \\
& +\sum_{t-j}^{p} \psi_{33} e r_{t-j}+\sum_{t-j}^{p} \psi_{34} a_{p t-j}+\sum_{t-j}^{p} \psi_{35} m l r_{t-j}+\sum_{t-j}^{p} \psi_{36} c r_{t-j}+\sum_{t-j}^{p} \psi_{37} c r s_{t-j}+\sum_{t-j}^{p} \psi_{38} m 2_{t-j} \\
& +\sum_{t-j}^{p} \psi_{39} x_{t-j}+\varepsilon_{t}^{e r_{t}}
\end{aligned}
$$$$
a_{p t}=\phi_{40}-m p r_{t}-i_{t}-e r_{t}-m l r_{t}-c r_{t}-c r s_{t}-m 2_{t}-x_{t}+\sum_{t-j}^{p} \psi_{41} m p r_{t-j}+\sum_{t-j}^{p} \psi_{42} i_{t-j}
$$$$
+\sum_{t-j}^{p} \psi_{43} e r_{t-j}+\sum_{t-j}^{p} \psi_{44} a_{p t-j}+\sum_{t-j}^{p} \psi_{45} m l r_{t-j}+\sum_{t-j}^{p} \psi_{46} c r_{t-j}+\sum_{t-j}^{p} \psi_{47} c r s_{t-j}+\sum_{t-j}^{p} \psi_{48} m 2_{t-j}
$$$$
+\sum_{t-j}^{p} \psi_{49} x_{t-j}+\varepsilon_{t}^{a_{p t}}
$$$$
m l r_{t}=\phi_{50}-m p r_{t}-i_{t}-e r_{t}-a_{p t}-c r_{t}-c r s_{t}-m 2_{t}-x_{t}+\sum_{t-j}^{p} \psi_{51} m p r_{t-j}+\sum_{t-j}^{p} \psi_{52} i_{t-j}
$$$$
+\sum_{t-j}^{p} \psi_{53} e r_{t-j}+\sum_{t-j}^{p} \psi_{54} a_{p t-j}+\sum_{t-j}^{p} \psi_{55} m l r_{t-j}+\sum_{t-j}^{p} \psi_{56} c r_{t-j}+\sum_{t-j}^{p} \psi_{57} c r s_{t-j}+\sum_{t-j}^{p} \psi_{58} m 2_{t-j}
$$$$
+\sum_{t-j}^{p} \psi_{59} x_{t-j}+\varepsilon_{t}^{m l r_{t}}
$$$$
c r_{t}=\phi_{60}-m p r_{t}-i_{t}-e r_{t}-a_{p t}-m l r_{t}-c r s_{t}-m 2_{t}-x_{t}+\sum_{t-j}^{p} \psi_{61} m p r_{t-j}+\sum_{t-j}^{p} \psi_{62} i_{t-j}
$$$$
+\sum_{t-j}^{p} \psi_{63} e r_{t-j}+\sum_{t-j}^{p} \psi_{64} a_{p t-j}+\sum_{t-j}^{p} \psi_{65} m l r_{t-j}+\sum_{t-j}^{p} \psi_{66} c r_{t-j}+\sum_{t-j}^{p} \psi_{67} c r s_{t-j}+\sum_{t-j}^{p} \psi_{68} m 2_{t-j}
$$$$
+\sum_{t-j}^{p} \psi_{69} x_{t-j}+\varepsilon_{t}^{c r_{t}}
$$

$$
\begin{aligned}
& c r s_{t}=\phi_{70}-m p r_{t}-i_{t}-e r_{t}-a_{p t}-m l r_{t}-c r_{t}-m 2_{t}-x_{t}+\sum_{t-j}^{p} \psi_{71} m p r_{t-j}+\sum_{t-j}^{p} \psi_{72} i_{t-j} \\
& +\sum_{t-j}^{p} \psi_{73} e r_{t-j}+\sum_{t-j}^{p} \psi_{74} a_{p t-j}+\sum_{t-j}^{p} \psi_{75} m l r_{t-j}+\sum_{t-j}^{p} \psi_{76} c r_{t-j}+\sum_{t-j}^{p} \psi_{77} c r s_{t-j}+\sum_{t-j}^{p} \psi_{78} m 2_{t-j} \\
& +\sum_{t-j}^{p} \psi_{79} x_{t-j}+\varepsilon_{t}^{c r s_{t}}
\end{aligned}
$$




$$
\begin{aligned}
& m 2_{t}=\phi_{80}-m p r_{t}-i_{t}-e r_{t}-a_{p t}-m l r_{t}-c r_{t}-c r s_{t}-x_{t}+\sum_{t-j}^{p} \psi_{81} m p r_{t-j}+\sum_{t-j}^{p} \psi_{82} i_{t-j} \\
& +\sum_{t-j}^{p} \psi_{83} e r_{t-j}+\sum_{t-j}^{p} \psi_{84} a_{p t-j}+\sum_{t-j}^{p} \psi_{85} m l r_{t-j}+\sum_{t-j}^{p} \psi_{86} c r_{t-j}+\sum_{t-j}^{p} \psi_{87} c r s_{t-j}+\sum_{t-j}^{p} \psi_{88} m 2_{t-j} \\
& +\sum_{t-j}^{p} \psi_{89} x_{t-j}+\varepsilon_{t}^{m 2_{t}} \\
& x_{t}=\phi_{90}-m p r_{t}-i_{t}-e r_{t}-a_{p t}-m l r_{t}-c r_{t}-c r s_{t}-m 2_{t}+\sum_{t-j}^{p} \psi_{91} m p r_{t-j}+\sum_{t-j}^{p} \psi_{92} i_{t-j} \\
& +\sum_{t-j}^{p} \psi_{93} e r_{t-j}+\sum_{t-j}^{p} \psi_{94} a_{p t-j}+\sum_{t-j}^{p} \psi_{95} m l r_{t-j}+\sum_{t-j}^{p} \psi_{96} c r_{t-j}+\sum_{t-j}^{p} \psi_{97} c r s_{t-j}+\sum_{t-j}^{p} \psi_{98} m 2_{t-j} \\
& +\sum_{t-j}^{p} \psi_{99} x_{t-j}+\varepsilon_{t}^{x_{t}}
\end{aligned}
$$

The structural shocks $\varepsilon_{t}^{m p r_{t}}, \varepsilon_{t}^{i_{t}}, \varepsilon_{t}^{e r_{t}}, \varepsilon_{t}^{a_{p t}}, \varepsilon_{t}^{m l_{t}}, \varepsilon_{t}^{c r_{t}}, \varepsilon_{t}^{c r s_{t}}, \varepsilon_{t}^{m 2_{t}}, \varepsilon_{t}^{x_{t}}$ are serially uncorrelated with zero mean; the variance co-variance matrix is constant over time; the structural shocks are independent, identically distributed, as presented in equation (11).

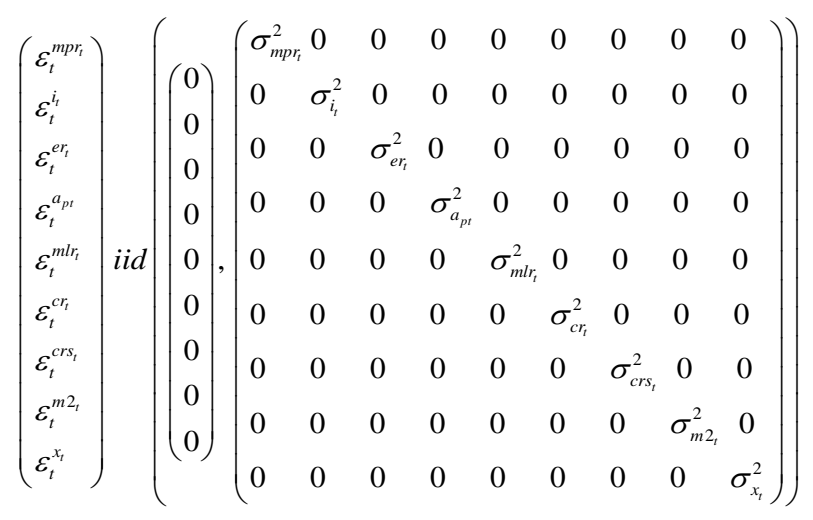

Equations (2) to (10) are expressed in matrix form, as the endogenous variables in each equation are expressed in terms of lag values of other endogenous variables. This is shown in equation (12).

$$
\left(\begin{array}{lllllllll}
1 & a_{12} & a_{13} & a_{14} & a_{15} & a_{16} & a_{17} & a_{18} & a_{19} \\
a_{21} & 1 & a_{23} & a_{24} & a_{25} & a_{26} & a_{27} & a_{28} & a_{29} \\
a_{31} & a_{32} & 1 & a_{34} & a_{35} & a_{36} & a_{37} & a_{38} & a_{39} \\
a_{41} & a_{42} & a_{43} & 1 & a_{45} & a_{46} & a_{47} & a_{48} & a_{49} \\
a_{51} & a_{52} & a_{53} & a_{54} & 1 & a_{56} & a_{57} & a_{58} & a_{59} \\
a_{61} & a_{62} & a_{63} & a_{64} & a_{65} & 1 & a_{67} & a_{68} & a_{69} \\
a_{71} & a_{72} & a_{73} & a_{74} & a_{75} & a_{76} & 1 & a_{78} & a_{79} \\
a_{81} & a_{82} & a_{83} & a_{84} & a_{85} & a_{86} & a_{87} & 1 & a_{89} \\
a_{91} & a_{92} & a_{93} & a_{94} & a_{95} & a_{96} & a_{97} & a_{98} & 1
\end{array}\right)\left(\begin{array}{l}
m p r_{t} \\
i_{t} \\
e r_{t} \\
a_{p t} \\
m r_{t} \\
c r_{t} \\
c r s_{t} \\
m 2_{t} \\
x_{t}
\end{array}\right)=\left(\begin{array}{l}
\phi_{10} \\
\phi_{20} \\
\phi_{30} \\
\phi_{40} \\
\phi_{50} \\
\phi_{60} \\
\phi_{70} \\
\phi_{80} \\
\phi_{90}
\end{array}\right)+\left(\begin{array}{lllllllll}
\psi_{11} & \psi_{12} & \psi_{13} & \psi_{14} & \psi_{15} & \psi_{16} & \psi_{17} & \psi_{18} & \psi_{19} \\
\psi_{21} & \psi_{22} & \psi_{23} & \psi_{24} & \psi_{25} & \psi_{26} & \psi_{27} & \psi_{28} & \psi_{29} \\
\psi_{31} & \psi_{32} & \psi_{33} & \psi_{34} & \psi_{35} & \psi_{36} & \psi_{37} & \psi_{38} & \psi_{39} \\
\psi_{41} & \psi_{42} & \psi_{43} & \psi_{44} & \psi_{45} & \psi_{46} & \psi_{47} & \psi_{48} & \psi_{49} \\
\psi_{51} & \psi_{52} & \psi_{53} & \psi_{54} & \psi_{55} & \psi_{56} & \psi_{57} & \psi_{58} & \psi_{59} \\
\psi_{61} & \psi_{62} & \psi_{63} & \psi_{64} & \psi_{65} & \psi_{66} & \psi_{67} & \psi_{68} & \psi_{69} \\
\psi_{71} & \psi_{72} & \psi_{73} & \psi_{74} & \psi_{75} & \psi_{76} & \psi_{77} & \psi_{78} & \psi_{79} \\
\psi_{81} & \psi_{82} & \psi_{83} & \psi_{84} & \psi_{85} & \psi_{86} & \psi_{87} & \psi_{88} & \psi_{89} \\
\psi_{81} & \psi_{82} & \psi_{83} & \psi_{84} & \psi_{85} & \psi_{86} & \psi_{87} & \psi_{88} & \psi_{89}
\end{array}\right)
$$




$$
\left(\begin{array}{l}
m p r_{t-j} \\
i_{t-j} \\
e r_{t-j} \\
a_{p t-j} \\
m l r_{t-j} \\
c r_{t-j} \\
c r s_{t-j} \\
m 2_{t-j} \\
x_{t-j}
\end{array}\right)+\left(\begin{array}{l}
\varepsilon_{t}^{m p r_{t}} \\
\varepsilon_{t}^{i_{t}} \\
\varepsilon_{t}^{e r_{t}} \\
\varepsilon_{t}^{a_{p t}} \\
\varepsilon_{t}^{m l r_{t}} \\
\varepsilon_{t}^{c r_{t}} \\
\varepsilon_{t}^{c r s_{t}} \\
\varepsilon_{t}^{m 2_{t}} \\
\varepsilon_{t}^{x_{t}}
\end{array}\right)
$$

The above structural form cannot be estimated with OLS because the regressors are correlated with the error term; this is one major problem with structural equations. This violates an important assumption of OLS and as such, no reliable estimates can be arrived at (Claudia and Massimiliano 2014). However, this problem is solved by considering equation (1) in its reduced form, as the equation is pre-multiplied by the inverse of the coefficient matrix of the vector of the endogenous macroeconomic variables $y_{t}$. This is achieved below:

$$
\mathrm{A}^{-1} \mathrm{~A} y_{t}=\mathrm{A}^{-1} \phi+\sum_{j=1}^{p} \mathrm{~A}^{-1} \psi_{j} y_{t-j}+\mathrm{A}^{-1} \Gamma \varepsilon_{t}
$$

By simplification $y_{t}=\mathrm{A}^{-1} \phi+\sum_{j=1}^{p} \mathrm{~A}^{-1} \psi_{j} y_{t-j}+\mathrm{A}^{-1} \Gamma \varepsilon_{t} ; \longrightarrow y_{t}=h+\sum_{j=1}^{p} \mathrm{~B}_{j} y_{t}+l$

Where $h=\mathrm{A}^{-1} \phi ; \mathrm{B}_{j}=\mathrm{A}^{-1} \psi_{j} ; u_{t}=\mathrm{A}^{-1} \Gamma \varepsilon_{t} ;$ For $\quad j=1, \ldots, P$;

$\Sigma_{u}=\mathrm{E}\left(u_{t} u_{t}^{\prime}\right)=\mathrm{A}^{-1} \Gamma \mathrm{E}\left(\varepsilon_{t} \varepsilon_{t}^{\prime}\right) \mathrm{A}^{-1} \Gamma^{\prime}=\mathrm{A}^{-1} \Gamma \Gamma^{-1} \Omega \mathrm{A}^{-\prime^{\prime}}=\mathrm{A}^{-1} \Omega \mathrm{A}^{-1^{\prime}} ; \Gamma \Gamma^{-1}=\mathrm{I} ;$

$\Sigma_{u}=\mathrm{A}^{-1} \Omega \mathrm{A}^{-1} ; u_{t} \sim \operatorname{iid} N_{n}\left(0, \Sigma_{u}\right)$

Therefore, equation (12) in its reduced form becomes:

$$
\left(\begin{array}{l}
m p r_{t} \\
i_{t} \\
e r_{t} \\
a_{p t} \\
m l r_{t} \\
c r_{t} \\
c r s_{t} \\
m 2_{t} \\
x_{t}
\end{array}\right)=\left(\begin{array}{l}
h_{10} \\
h_{20} \\
h_{30} \\
h_{40} \\
h_{50} \\
h_{60} \\
h_{70} \\
h_{80} \\
h_{90}
\end{array}\right)+\left(\begin{array}{lllllllll}
B_{11} & B_{12} & B_{13} & B_{14} & B_{15} & B_{16} & B_{17} & B_{18} & B_{19} \\
B_{21} & B_{22} & B_{23} & B_{24} & B_{25} & B_{26} & B_{27} & B_{28} & B_{29} \\
B_{31} & B_{32} & B_{33} & B_{34} & B_{35} & B_{36} & B_{37} & B_{38} & B_{39} \\
B_{41} & B_{42} & B_{43} & B_{44} & B_{45} & B_{46} & B_{47} & B_{48} & B_{49} \\
B_{51} & B_{52} & B_{53} & B_{54} & B_{55} & B_{56} & B_{57} & B_{58} & B_{59} \\
B_{61} & B_{62} & B_{63} & B_{64} & B_{65} & B_{66} & B_{67} & B_{68} & B_{69} \\
B_{71} & B_{72} & B_{73} & B_{74} & B_{75} & B_{76} & B_{77} & B_{78} & B_{79} \\
B_{81} & B_{82} & B_{83} & B_{84} & B_{85} & B_{86} & B_{87} & B_{88} & B_{89} \\
B_{91} & B_{92} & B_{93} & B_{94} & B_{95} & B_{96} & B_{97} & B_{98} & B_{99}
\end{array}\right) *\left(\begin{array}{l}
m p r_{t-j} \\
i_{t-j} \\
e r_{t-j} \\
a_{p t-j} \\
m l r_{t-j} \\
c r_{t-j} \\
c r s_{t-j} \\
m 2_{t-j} \\
x_{t-j}
\end{array}\right)+\left(\begin{array}{l}
u_{t}^{m p r_{t}} \\
u_{t}^{i_{t}} \\
u_{t}^{e r_{t}} \\
u_{t}^{a_{p t}} \\
u_{t}^{m r_{t}} \\
u_{t}^{c r_{t}} \\
u_{t}^{c r s_{t}} \\
u_{t}^{m 2_{t}} \\
u_{t}^{x_{t}}
\end{array}\right)
$$


The reduced-form VAR error terms $u_{t}^{m p r_{t}}, u_{t}^{i_{t}}, u_{t}^{e r_{t}}, u_{t}^{a_{p t}}, u_{t}^{m l r_{t}}, u_{t}^{c r_{t}}, u_{t}^{c r s_{t}}, u_{t}^{m 2_{t}}, u_{t}^{x_{t}}$ are also serially uncorrelated with zero mean; the variance co-variance matrix is also constant over time. The error terms are also independent, identically distributed, as presented in equation (14).



However, the reduced-form VARs cannot explain the structure of the economy, so therefore the reduced-form error terms, $u_{t}$, cannot be interpreted as structural shocks; and it is impossible to uniquely determined the parameters $\phi, \mathrm{A}, \psi_{1}, \ldots, \psi_{p}, \Omega$ from $h, \mathrm{~B}_{1}, \ldots, \mathrm{B}_{p}, \sum_{u}$. The estimated SVAR can only be used to generate impulse response functions that explain the time-dynamic effects of the monetary shocks on real output, when the shocks have been correctly identified. In literature, one of the solutions that is common in empirical research to solving this identification problem is by zero short-run restrictions (also known as Cholesky identification, recursive identification). Cooley and LeRoy (1985) argued that since different variable ordering yields different structural parameters the recursive identification procedure is arbitrary and it cannot be interpreted as a structural model. An alternative non-recursive restriction on the contemporaneous interactions among variables was introduced in the works of Bernanke (1986), Blanchard and Watson (1986) and Sims (1986), in which the identification method allows for a theory based-restrictions that represent a meaningful relationship between the variables and the structural shocks. This is theoretically and empirically plausible. The restrictions may not be a triangular form, in as much as the identification conditions are met. When $\Omega$ is normalized as an identity matrix such as $\Omega=\mathrm{I}_{k}, \sum_{u}$ becomes $\sum_{u}=\mathrm{A}^{-1} \mathrm{~A}^{-1}$, which is symmetric and represents a system of $K(K+1) / 2$ independent equations. The system can then be solved for the unknown parameters $\mathrm{A}^{-1}$, provided the number of unknown parameters in $\mathrm{A}^{-1}$ is not more than the number of independent equations in $\sum_{u}=\mathrm{A}^{-1} \mathrm{~A}^{-1}$. This demands the imposition of additional restrictions on selected elements of $\mathrm{A}^{-1}$ by making them to be zero. This restriction is $K(K-1) / 2$ zero parameters in A matrix, which is the coefficient matrix of the vector of endogenous variables in the model. The model is identified below, using theoretical underpinnings as the basis. 


$$
\mathrm{A} y_{t}=\left(\begin{array}{lllllllll}
1 & a_{12} & 0 & 0 & 0 & 0 & a_{17} & 0 & 0 \\
a_{21} & 1 & a_{23} & 0 & 0 & 0 & 0 & 0 & a_{29} \\
0 & a_{32} & 1 & 0 & 0 & 0 & 0 & 0 & 0 \\
0 & 0 & 0 & 1 & 0 & 0 & 0 & 0 & 0 \\
0 & 0 & 0 & 0 & 1 & 0 & 0 & 0 & a_{59} \\
0 & 0 & 0 & 0 & a_{65} & 1 & 0 & 0 & 0 \\
0 & a_{72} & 0 & 0 & a_{75} & a_{76} & 1 & 0 & 0 \\
0 & 0 & 0 & 0 & 0 & 0 & 0 & 1 & a_{89} \\
a_{91} & a_{92} & a_{93} & a_{94} & a_{95} & a_{96} & a_{97} & a_{98} & 1
\end{array}\right)\left(\begin{array}{l}
m p r_{t} \\
i_{t} \\
e r_{t} \\
a_{p t} \\
m l r_{t} \\
c r_{t} \\
c r s_{t} \\
m 2_{t} \\
x_{t}
\end{array}\right)
$$

\section{Summary of Theoretical and Empirical Justification of Contemporaneous Response Among Variables}

$a_{12}=$ ("mpr" responds contemporaneously to shocks from " $i$ "). It is empirically and theoretically plausible that monetary authority will adjust the monetary policy rate based on the activities in the banking system, which is best explained by market interest rate.

$a_{17}=$ ("mpr" responds contemporaneously to shocks from "crs"). The short term interest rate and bank lending rate are affected by changes in monetary policy rate which consequently affect the quantity of credit to the real sector; it may also be plausible to trace the indirect effect of the official interest rate on credit made available to the real sector by the banking system.

$a_{21}=$ (" $i$ " responds contemporaneously to shocks from "mpr"). Theoretically a change to the official interest rate leads to a corresponding change in the market interest rate.

$a_{23}=$ (" $i "$ responds contemporaneously to shocks from "er"). Empirically and theoretically, when exchange rate falls, assets denominated in local currency suffer exchange rate risk. As a result of this, foreign investors will demand for a higher interest rate to invest in domestic assets.

$a_{29}=\quad$ (" $i$ " responds contemporaneously to shocks from "real output"). As real output increases, more money is required to buy goods and services; the owners of real and financial assets offer them for sale and this brings down prices of these assets. As prices of these assets come down, interest rate increases, as there exist an inverse relationship between interest rate and price of asset.

$a_{32}=\quad$ ('er' responds contemporaneously to shocks from " $i$ "). A decrease in domestic interest rate will lead to lower returns on domestic assets when compared to foreign assets. This will result in capital outflows which then leads to depreciation of the domestic currency that affects the exchange rate.

$a_{59}=$ ('mlr' responds contemporaneously to shocks from "real output"). Besides the credit given by banks to their credit worthy customers, the other category of customers are the perceived risky real investors who also get credit from banks to invest in productive sectors. As these productive investors demand for credit at a lower maximum lending rate, banks supply credit at a higher maximum lending rate. There is a meeting point in all of this, where credit is made available for productive investment purposes. This eventually leads to an increase in real output.

$a_{65}=$ ('cr' responds contemporaneously to shocks from " $m l r$ "). When the risk of default becomes on the increase, the banks in response reduce the quantity of credit to the perceived risky investors.

$a_{72}=$ ("crs" responds contemporaneously to shocks from " $i$ "). A reduction in the market interest rate is expected to lead to an increase in investment and credit to real sector. 
$a_{75}=$ ("crs" responds contemporaneously to shocks from " $m l r$ "). The amount of credit loans banks give to their perceived risky customers is dependent on the maximum lending rate. If this rate increases, all things being equal, banks offer more loans and cut down on loans if the rate decreases.

$a_{76}=$ ("crs" responds contemporaneously to shocks from "cr"). With a rise in the risk of default, there will be a higher probability of non-performing loans being accumulated. In response to this, banks will lower their credit to the real sector.

$a_{89}=$ (" $m 2$ " responds contemporaneously to shocks from "real output"). An increase real output will require more money to transact it, all things being equal.

$a_{91}=$ ("real output" responds contemporaneously to shocks from "mpr"). The monetary policy rate is the official interest rate which other short term interest rates majorly anchors on. Changes in monetary policy rate affects the real output through the short term interest rate and other monetary policy channels. The contemporaneous response of the real output to the official interest rate may also occur.

$a_{92}=$ ("real output" responds contemporaneously to shocks from " $i$ "). Following the IS-LM framework, a change in interest rate will affect real output through investment.

$a_{93}=$ ("real output" responds contemporaneously to shocks from "er"). A change in exchange rate affects real output, in the exchange rate transmission channel of monetary policy.

$a_{94}=$ ("real output" responds contemporaneously to shocks from "ap"). A fall in stock prices results to a decrease in the value of financial wealth and the lifetime resources of consumers. This consequently leads to a reduction in consumption and output.

$a_{95}=$ ("real output" responds contemporaneously to shocks from " $m l r$ "). The real output will respond to shock from the maximum lending rate. This is because more investments are made as banks lend to the real sector, which eventually leads to a rise in the real output.

$a_{97}=$ ("real output" responds contemporaneously to shocks from "crs"). A rise in credit to real the real will affect real output through investment.

$a_{98}=$ ("real output" responds contemporaneously to shocks from " $m 2$ "). Following the IS-LM framework, an increase or decrease in money supply will shift the LM curve to the right or left respectively, with a corresponding increase or decrease in real output.

\section{Data Description and Sources}

The description and sources of the data used for the study are detailed in Table 1. All the variables were adjusted for seasonal variation before entering their log forms.

Table 1. Data description and sources

\begin{tabular}{lll}
\hline Variable & Definition & Source \\
\hline $\mathrm{mpr}$ & $\begin{array}{l}\text { Monetary Policy Rate: This is the official interest rate of the Central Bank of } \\
\text { Nigeria. }\end{array}$ & CBN Statistical Bulletin, 2018 \\
\hline $\mathrm{i}$ & Market Interest Rate: This is the short term interest rate. & CBN Statistical Bulletin, 2018 \\
\hline $\mathrm{m} 2$ & Broad Money Supply: This is the broad money in the economy at a given time. & CBN Statistical Bulletin, 2018 \\
\hline $\mathrm{er}$ & $\begin{array}{l}\text { Nominal Exchange Rate: This is the rate at which Nigeria's currency is } \\
\text { exchanged for other currencies of the world, such as US dollar. }\end{array}$ & CBN Statistical Bulletin, 2018 \\
\hline $\mathrm{ap}$ & Asset Prices: This is equity price proxy as asset prices. & CBN Statistical Bulletin, 2018 \\
\hline $\mathrm{mlr}$ & $\begin{array}{l}\text { Maximum Lending Rate: It is the rate at which the banks lend to their perceived } \\
\text { risky customers. }\end{array}$ & CBN Statistical Bulletin, 2018 \\
\hline
\end{tabular}




\begin{tabular}{lll}
\hline crs & $\begin{array}{l}\text { Credit to real sector: This is the amount of credit loan advanced to the real sector } \\
\text { by banks. }\end{array}$ & CBN Statistical Bulletin, 2018 \\
\hline cr & $\begin{array}{l}\text { Credit Risk: This is the risk of default in loan repayment obligations. The } \\
\text { definition and calculation of credit risk by De Guimarães and Feijó (2011) is } \\
\text { adopted by this study. They defined credit risk as the percentage of loans a bank } \\
\text { expects to go unpaid. This is calculated as a percentage of: } \\
\text { Provision for bad loans / Nonperforming loans. }\end{array}$ & $\begin{array}{l}\text { Computed by Researcher from } \\
\text { CBN Statistical Bulletin, 2018 }\end{array}$ \\
& $\begin{array}{l}\text { Aggregate real output: This is the total real output in the economy at a given } \\
\text { quarter. }\end{array}$ & National Bureau of Statistics \\
\hline $\mathrm{Xt}$ &
\end{tabular}

\section{Results and Discussions}

\subsection{Diagnostic Test}

Augmented Dickey-Fuller and Phillips Perron were used to test the stationarity of the variables used. All the variables were stationary at first difference as shown in Table 2. In testing for the lag length criteria, the study considered Akaike information criterion (AIC), Hannan-Quinn information criterion (HQ), Schwartz information criterion (SC), and Final Prediction Error (FPE). The lag length corresponding to the asterisk ${ }^{*}$ ) sign in each of these criteria indicates the respective optimum lag. In Figure 1, most of the lag length information criteria considered lag three as the optimum lag. This therefore justifies the choice of lag three as the chosen lag for this study. Evidence from Figure 2 and Figure 3 showed that the reduced VAR is stable, as all roots have modulus less than one and lie inside the unit circle. The result of the normality test conducted in Table 3 indicate that the residual of the models satisfies the normality condition, as probability value corresponding to the Jarque-Bera statistics is more than $5 \%$. Therefore, the residuals are multivariate normal. In Table 4, there is no violation of the assumption of serial independence of the residuals in all the lag periods in the model. The probability values are more than five percent, including lag three.

Table 2. Summary of Unit Root Test

\begin{tabular}{|c|c|c|c|c|c|c|c|c|c|c|c|c|}
\hline \multirow[b]{3}{*}{ Variables } & \multicolumn{6}{|c|}{ Augmented Dickey-Fuller } & \multicolumn{6}{|c|}{ Philips-Perron } \\
\hline & \multirow{2}{*}{\multicolumn{2}{|c|}{$\begin{array}{l}\text { Level } \\
\text { Critical } \\
\text { Values }\end{array}$}} & \multirow[b]{2}{*}{ Remark } & \multicolumn{3}{|c|}{ 1st Difference } & \multicolumn{3}{|c|}{ Level } & \multicolumn{3}{|c|}{ 1st Difference } \\
\hline & & & & $\begin{array}{c}\text { Observed } \\
\text { Values }\end{array}$ & $\begin{array}{l}\text { Critical } \\
\text { Values }\end{array}$ & Remark & $\begin{array}{c}\text { Observed } \\
\text { Values }\end{array}$ & $\begin{array}{l}\text { Critical } \\
\text { Values }\end{array}$ & Remark & $\begin{array}{c}\text { Observed } \\
\text { Values }\end{array}$ & $\begin{array}{l}\text { Critical } \\
\text { Values }\end{array}$ & Remark \\
\hline & & & Non & & \multirow{3}{*}{-2.933158} & & & \multirow{3}{*}{-2.9314} & Non & & \multirow{3}{*}{-2.93316} & \\
\hline \multirow[t]{2}{*}{ lmpr_d11 } & -1.45740 & -2.9332 & Stationary & -3.736655 & & Stationary & -1.22240 & & Stationary & -3.73633 & & Stationary \\
\hline & & & Non & & & & & & Non & & & \\
\hline \multirow[t]{2}{*}{ li_d11 } & -1.86599 & -2.9314 & Stationary & -5.605062 & -2.933158 & Stationary & -2.21950 & -2.9314 & Stationary & -5.63109 & -2.93316 & Stationary \\
\hline & & & Non & & & & -0.48502 & & Non & & & \\
\hline ler_d11 & -0.4133 & -2.93140 & Stationary & -5.756282 & -2.933158 & Stationary & 0 & -2.9314 & Stationary & -5.7443 & -2.933158 & Stationary \\
\hline \multirow[t]{2}{*}{ lap_d11 } & -3.25354 & -2.9332 & Stationary & -4.29891 & \multirow{2}{*}{-2.933158} & Stationary & -3.05610 & \multirow[t]{2}{*}{-2.9314} & Stationary & -4.26058 & \multirow[t]{2}{*}{-2.93316} & Stationary \\
\hline & & & Non & & & & & & Non & & & \\
\hline \multirow[t]{2}{*}{ lmlr_d11 } & -1.8314 & -2.93316 & Stationary & -3.429799 & \multirow[t]{2}{*}{-2.933158} & Stationary & -2.05062 & \multirow{2}{*}{-2.9314} & Stationary & -3.2746 & \multirow[t]{2}{*}{-2.933158} & Stationary \\
\hline & & & Non & & & & -2.04996 & & Non & & & \\
\hline \multirow[t]{2}{*}{ lcr_d11 } & -1.8363 & -2.9314 & Stationary & -6.797604 & -2.933158 & Stationary & 2 & -2.9314 & Stationary & -6.8011 & -2.933158 & Stationary \\
\hline & & & Non & & & & -2.70838 & & Non & & & \\
\hline \multirow[t]{2}{*}{ lcrs_d11 } & -2.7839 & -2.93316 & Stationary & -4.177982 & -2.933158 & Stationary & 6 & -2.9314 & Stationary & -4.1233 & -2.933158 & Stationary \\
\hline & & & Non & & & & -3.43593 & & & & & \\
\hline \multirow[t]{2}{*}{ lm2_d11 } & -1.1491 & -2.93140 & Stationary & -6.024523 & -2.938987 & Stationary & 8 & -2.9314 & Stationary & -8.3387 & -2.933158 & Stationary \\
\hline & & & & & & & -2.35812 & & Non & & & \\
\hline 1xt_d11 & -4.1837 & -2.94840 & Stationary & -10.30016 & -2.951125 & Stationary & 7 & -2.9314 & Stationary & -6.1734 & -2.933158 & Stationary \\
\hline
\end{tabular}

Source: Author's computation using Eviews 10 
VAR Lag Order Selection Criteria

Endogenous variables: DLOG(MPR_D11) DLOG(I_D11) DLOG(ER_D11) LOG(AP_D11)

DLOG(MLR_D11) DLOG(CR_D11) DLOG(CRS_D11) DLOG(M2_D11) DLOG(XT_D11)

Exogenous variables: $\mathrm{C}$

Date: 05/20/20 Time: 11:10

Sample: 2008Q1 2018Q4

Included observations: 40

\begin{tabular}{ccccccc}
\hline Lag & LogL & LR & FPE & AIC & SC & HQ \\
\hline 0 & 347.1892 & NA & $3.67 \mathrm{e}-19$ & -16.90946 & $-16.52946^{*}$ & -16.77206 \\
1 & 443.9474 & 145.1373 & $1.84 \mathrm{e}-19$ & -17.69737 & -13.89739 & -16.32342 \\
2 & 558.4974 & $120.2775^{*}$ & $6.57 \mathrm{e}-20$ & -19.37487 & -12.15491 & -16.76436 \\
3 & 708.3728 & 89.92521 & $2.02 \mathrm{e}-20^{*}$ & $-22.81864^{*}$ & -12.17870 & $-18.97157^{*}$ \\
\hline
\end{tabular}

* indicates lag order selected by the criterion

LR: sequential modified LR test statistic (each test at 5\% level)

FPE: Final prediction error

AIC: Akaike information criterion

SC: Schwarz information criterion

HQ: Hannan-Quinn information criterion

Figure 1. Lag selection-order criteria

Author's computation using Eviews 10

Roots of Characteristic Polynomial

Endogenous variables: DLOG(MPR_D11)

DLOG(I_D11) DLOG(ER_D11)

LOG(AP_D11) DLOG(MLR_D11)

DLOG(CR_D11) DLOG(CRS_D11)

DLOG(M2_D11) DLOG(XT_D11)

Exogenous variables: $\mathrm{C}$

Lag specification: 13

Date: 05/20/20 Time: 13:23

\begin{tabular}{cc}
\hline Root & Modulus \\
\hline $0.888400+0.249932 \mathrm{i}$ & 0.922887 \\
$0.888400-0.249932 \mathrm{i}$ & 0.922887 \\
$-0.096978+0.870789 \mathrm{i}$ & 0.876173 \\
$-0.096978-0.870789 \mathrm{i}$ & 0.876173 \\
-0.868822 & 0.868822 \\
$0.427374+0.755601 \mathrm{i}$ & 0.868091 \\
$0.427374-0.755601 \mathrm{i}$ & 0.868091 \\
$-0.539372-0.655268 \mathrm{i}$ & 0.848704 \\
$-0.539372+0.655268 \mathrm{i}$ & 0.848704 \\
$0.721475+0.446236 \mathrm{i}$ & 0.848323 \\
$0.721475-0.446236 \mathrm{i}$ & 0.848323 \\
$-0.765695+0.265342 \mathrm{i}$ & 0.810367 \\
$-0.765695-0.265342 \mathrm{i}$ & 0.810367 \\
$-0.426385-0.685391 \mathrm{i}$ & 0.807196 \\
$-0.426385+0.685391 \mathrm{i}$ & 0.807196 \\
$0.589314+0.516215 \mathrm{i}$ & 0.783434 \\
$0.589314-0.516215 \mathrm{i}$ & 0.783434 \\
$0.242596-0.740236 \mathrm{i}$ & 0.778975
\end{tabular}




\begin{tabular}{cc}
$0.242596+0.740236 \mathrm{i}$ & 0.778975 \\
$-0.535690-0.524130 \mathrm{i}$ & 0.749450 \\
$-0.535690+0.524130 \mathrm{i}$ & 0.749450 \\
$0.482393+0.528955 \mathrm{i}$ & 0.715889 \\
$0.482393-0.528955 \mathrm{i}$ & 0.715889 \\
-0.583183 & 0.583183 \\
0.429458 & 0.429458 \\
-0.138106 & 0.138106 \\
0.075848 & 0.075848 \\
\hline
\end{tabular}

No root lies outside the unit circle.

VAR satisfies the stability condition.

Figure 2. Stability condition table

Author's computation using Eviews 10

\section{Inverse Roots of AR Characteristic Polynomial}

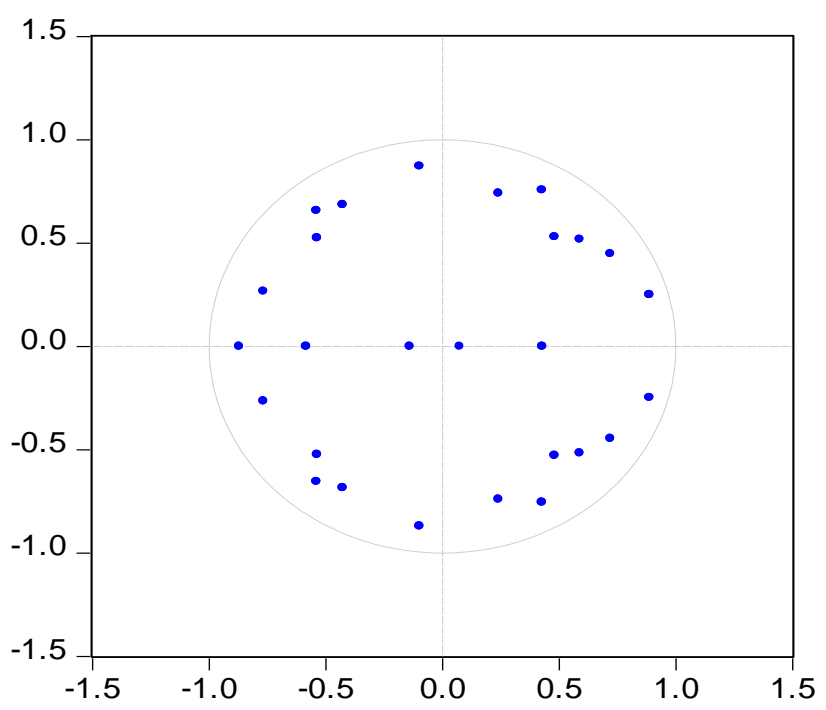

Figure 3. Stability condition graph

Author's computation using Eviews 10

Table 3. Summary of normality test result

\begin{tabular}{ccccc}
\hline Component & Jarque-Bera & df & & Probability \\
\hline 1 & 0.608553 & 2 & 0.7377 \\
2 & 2.181182 & 2 & 0.3360 \\
3 & 0.168824 & 2 & 0.9191 \\
4 & 13.23133 & 2 & 0.0013 \\
5 & 1.237039 & 2 & 0.5387 \\
6 & 2.497583 & 2 & 0.2869 \\
& 7 & 4.415455 & 2 & 0.1100 \\
& 8 & 0.513730 & 2 & 0.7735 \\
& 9 & 0.205715 & 2 & 0.9023 \\
\hline Joint & 25.05941 & 18 & 0.1233 \\
\hline
\end{tabular}

*Approximate p-values do not account for coefficient

Author's computation using Eviews 10 
Table 4. Summary of Serial Correlation LM Test

VAR Residual Serial Correlation LM Tests

Date: 08/11/20 Time: 11:20

Sample: 2008Q1 2018Q4

Included observations: 40

\begin{tabular}{|c|c|c|c|c|c|c|}
\hline \multicolumn{7}{|c|}{$\begin{array}{c}\text { Null } \\
\text { hypothesis: } \\
\text { No serial } \\
\text { correlation } \\
\text { at lag h }\end{array}$} \\
\hline Lag & LRE* stat & $\mathrm{df}$ & Prob. & Rao F-stat & df & Prob. \\
\hline 1 & 64.46998 & 49 & 0.0682 & 1.430434 & $(49,29.8)$ & 0.1497 \\
\hline 2 & 68.20143 & 49 & 0.0361 & 1.578258 & $(49,29.8)$ & 0.0929 \\
\hline 3 & 70.29335 & 49 & 0.0247 & 1.665771 & $(49,29.8)$ & 0.0697 \\
\hline 4 & 50.81973 & 49 & 0.4018 & 0.969859 & $(49,29.8)$ & 0.5475 \\
\hline 5 & 59.85328 & 49 & 0.1377 & 1.261297 & $(49,29.8)$ & 0.2521 \\
\hline
\end{tabular}

\subsection{Discussion of Results}

Table 5. Summary of SVAR results - With effects of credit risk

\begin{tabular}{|c|c|c|c|c|c|c|c|c|c|}
\hline$m p r_{t}$ & $i_{t}$ & $e r_{t}$ & $a_{p t}$ & $m l r_{t}$ & $c r_{t}$ & $\mathrm{crs}_{t}$ & $m 2_{t}$ & $x_{t}$ & \\
\hline \multirow[t]{2}{*}{1} & 0.77475 & 0 & 0 & 0 & 0 & -25.6634 & 0 & 0 & $m p r_{t}$ \\
\hline & $(0.2157)$ & & \multicolumn{7}{|c|}{$(0.0000)^{* *}$} \\
\hline 9.274358 & 1 & -22.1947 & 0 & 0 & 0 & 0 & 0 & -1.29483 & $i_{t}$ \\
\hline$(0.0004)^{* * *}$ & & $(0.0000)^{* *}$ & & & & & & $(0.0005)^{* *}$ & \\
\hline \multirow[t]{2}{*}{0} & 3.82996 & 1 & 0 & 0 & 0 & 0 & 0 & 0 & $e r_{t}$ \\
\hline & $(0.0000)^{* *}$ & & & & & & & & \\
\hline 0 & 0 & 0 & 1 & 0 & 0 & 0 & 0 & 0 & $a_{p t}$ \\
\hline \multirow[t]{2}{*}{0} & 0 & 0 & 0 & 1 & 0 & 0 & 0 & 2.15196 & $m l r_{t}$ \\
\hline & & & & & & & & $(0.0000)^{* *}$ & \\
\hline \multirow[t]{2}{*}{0} & 0 & 0 & 0 & 50.50112 & 1 & 0 & 0 & 0 & $c r_{t}$ \\
\hline & & & & $(0.0000)^{* *}$ & & & & & \\
\hline \multirow[t]{2}{*}{0} & 2.34156 & 0 & 0 & -5.36294 & -10.720 & 1 & 0 & 0 & $c r s_{t}$ \\
\hline & $(0.0051)^{* *}$ & & & $(0.5974)$ & $(0.0000)^{* *}$ & & & & \\
\hline \multirow[t]{2}{*}{0} & 0 & 0 & 0 & 0 & 0 & 0 & 1 & 0.01981 & $m 2_{t}$ \\
\hline & & & & & & & & $(0.9537)$ & \\
\hline 18.12545 & -0.99348 & 5.65817 & 3.37563 & -63.1590 & -0.3916 & 22.2015 & 1.32250 & 1 & $x_{t}$ \\
\hline$(0.0000)^{* *}$ & $(0.3712)$ & $(0.2899)$ & $(0.2209)$ & $(0.0000)^{* *}$ & $(0.8510)$ & $(0.0001)^{* *}$ & $(0.8398)$ & & \\
\hline
\end{tabular}

Note: $* *$ indicates significant at $5 \%$ level, while * indicates significant at $10 \%$

Source: Author's computation using Eviews 10

The summary estimates of the contemporaneous response of the variables in the model to respective shocks are shown in Table 5. The effect of credit risk was considered. From the result, the estimate of contemporaneous response of credit to real sector to shock from credit risk is -10.720 , which is significant at $5 \%$. Which means that banks respond negatively to a high in credit risk and limit their credit to the real sector, which leads to a reduction in real output. 
Table 6. Summary of SVAR result - Without effects of credit risk

\begin{tabular}{|c|c|c|c|c|c|c|c|c|}
\hline$m p r_{t}$ & $i r_{t}$ & $n e r_{t}$ & $p_{e t}$ & $m l r_{t}$ & $c r s_{t}$ & $m 2_{t}$ & $x_{t}$ & \\
\hline 1 & $\begin{array}{c}0.551106 \\
(0.4233)\end{array}$ & 0 & 0 & 0 & $\begin{array}{l}-17.50668 \\
(0.0000)^{* *}\end{array}$ & 0 & 0 & $m p r_{t}$ \\
\hline $\begin{array}{c}10.45938 \\
(0.0000)^{* *}\end{array}$ & 1 & $\begin{array}{l}-17.83616 \\
(0.0000)^{* *}\end{array}$ & 0 & 0 & 0 & 0 & $\begin{array}{l}-0.746439 \\
(0.0485) * *\end{array}$ & $i r_{t}$ \\
\hline 0 & $\begin{array}{c}4.218764 \\
(0.0000)^{* *}\end{array}$ & 1 & 0 & 0 & 0 & 0 & 0 & $n e r_{t}$ \\
\hline 0 & 0 & 0 & 1 & 0 & 0 & 0 & 0 & $p_{e t}$ \\
\hline 0 & 0 & 0 & 0 & 1 & 0 & 0 & $\begin{array}{c}2.255184 \\
(0.0000)^{* *}\end{array}$ & $m l r_{t}$ \\
\hline 0 & $\begin{array}{l}-2.818380 \\
(0.0001)^{* *}\end{array}$ & 0 & 0 & $\begin{array}{c}59.50213 \\
(0.0000)^{* *}\end{array}$ & 1 & 0 & 0 & $c r s_{t}$ \\
\hline 0 & 0 & 0 & 0 & 0 & 0 & 1 & $\begin{array}{c}0.022412 \\
(0.9500)\end{array}$ & $m 2_{t}$ \\
\hline $\begin{array}{c}13.39432 \\
(0.0000)^{* *}\end{array}$ & $\begin{array}{c}-0.530685 \\
(0.5929)\end{array}$ & $\begin{array}{c}13.21013 \\
(0.0026)^{* *}\end{array}$ & $\begin{array}{c}0.965114 \\
(0.6384)\end{array}$ & $\begin{array}{l}-66.02009 \\
(0.0000)^{* *}\end{array}$ & $\begin{array}{c}12.89673 \\
(0.0002)^{* *}\end{array}$ & $\begin{array}{c}0.776310 \\
(0.8856)\end{array}$ & 1 & $x_{t}$ \\
\hline
\end{tabular}

Note: $* *$ indicates significant at $5 \%$ level, while * indicates significant at $10 \%$

Source: Author's computation using Eviews 10

Table 7. Variance decomposition of real output with effects of credit risk

\begin{tabular}{|c|c|c|c|c|c|c|c|c|c|c|}
\hline Variance & & & & & & & & & & \\
\hline $\begin{array}{l}\text { Decompositi } \\
\text { on of } \\
\text { DLOG(XT_ } \\
\text { D11): }\end{array}$ & & $\mathrm{mpr}$ & $\mathrm{i}$ & er & ap & $\mathrm{mlr}$ & $\mathrm{cr}$ & crs & $\mathrm{m} 2$ & $\mathrm{Xt}$ \\
\hline Period & S.E. & Shock1 & Shock2 & Shock3 & Shock4 & Shock5 & Shock6 & Shock7 & Shock8 & Shock9 \\
\hline 1 & 0.464802 & 7.94E-07 & $2.17 \mathrm{E}-07$ & 0.000130 & $4.09 \mathrm{E}-07$ & 99.95944 & 0.040078 & 0.000348 & $6.28 \mathrm{E}-08$ & $3.59 \mathrm{E}-08$ \\
\hline 2 & 2.783131 & 0.234488 & 0.288705 & 0.017986 & 95.03808 & 2.817767 & 0.040174 & 0.300658 & 1.052298 & 0.209841 \\
\hline 3 & 3.471976 & 1.085052 & 0.377166 & 0.410127 & 61.14110 & 2.119728 & 0.563593 & 0.193198 & 33.55118 & 0.558857 \\
\hline 4 & 3.676508 & 0.971061 & 0.341498 & 0.378797 & 58.15956 & 2.193567 & 0.870010 & 0.173193 & 36.38928 & 0.523032 \\
\hline 5 & 4.423427 & 0.698883 & 0.333504 & 0.295192 & 57.51398 & 1.554699 & 0.601009 & 0.202162 & 38.42993 & 0.370637 \\
\hline 6 & 4.490116 & 0.679341 & 0.381146 & 0.511134 & 56.06983 & 1.747014 & 1.373363 & 0.230964 & 38.64727 & 0.359938 \\
\hline 7 & 5.197238 & 0.509492 & 0.288782 & 0.412354 & 42.19824 & 1.305619 & 1.026808 & 0.173315 & 53.81673 & 0.268665 \\
\hline 8 & 5.393553 & 0.474072 & 0.268317 & 0.425128 & 40.19146 & 1.218573 & 0.954154 & 0.183768 & 56.03504 & 0.249490 \\
\hline 9 & 5.455807 & 0.466587 & 0.262238 & 0.550793 & 39.89951 & 1.190923 & 0.962358 & 0.179627 & 56.23613 & 0.251835 \\
\hline 10 & 5.564363 & 0.448715 & 0.252106 & 0.564462 & 41.67832 & 1.146956 & 0.934744 & 0.175987 & 54.54459 & 0.254116 \\
\hline Average & & 0.567692 & 0.2793462 & 0.356610 & 49.18901 & 11.52543 & 0.736629 & 0.181322 & 36.87024 & 0.304641 \\
\hline
\end{tabular}

Factorization: Structural

Table 7 is the result of forecast error variance decomposition of real output. It accounts for the variation in real output which is caused by its own structural shocks and those shocks from other endogenous variables in the model. 
Evidence from this result revealed that shocks from credit risk is responsible for about an average of $0.74 \%$ variation in real output, which is significant as shown in Table 5. Shocks from interest rate account for $0.28 \%$ variation in real output; shocks from exchange rate accounts for $0.36 \%$ variation in real output; shocks from asset price accounts for $49.19 \%$ variation in real output and shock from credit channel through money supply accounts for $36.87 \%$ variation in real output. The impulse response function result is shown in Table 8. From quarter one to quarter five, aggregate real output negatively responding to a shock from credit. In quarter six, it became positive and reversed back to negative between quarter seven and nine. In quarter ten, the reaction became positive again. This is in line with expectation, as banks are cautious in giving out credit during the period of a rise in credit risk, which negatively affect the real output. During a time when the risk of default is low, more credit is given out to the real sector for investment. As this happen, the real output is passively affected. This is also an evidence that the real output responds to shocks from credit risk. The forecast error variance decomposition of the model without the effects of credit risk is in Table 9, while the contemporaneous structural estimates are shown in Table 6. When compared with the result in Table 7, it is evident that credit risk in the model revealed vital information about the true order of the transmission channels of monetary policy actions to the real sector. For instance, the asset price channel of transmission is the most effective followed by credit channel; followed by exchange rate channel, while the interest rate channel is the least.

Table 8. Impulse response function of real output with effects of credit risk

\begin{tabular}{|c|c|c|c|c|c|c|c|c|c|}
\hline sponse & & & & & & & & & \\
\hline $\begin{array}{c}\operatorname{DLOG}\left(\mathrm{XT}_{-}\right. \\
\mathrm{D} 11):\end{array}$ & $\mathrm{mpr}$ & $\mathrm{i}$ & er & ap & $\mathrm{mlr}$ & $\mathrm{cr}$ & crs & $\mathrm{m} 2$ & $\mathrm{Xt}$ \\
\hline Period & Shock1 & Shock2 & Shock3 & Shock4 & Shock5 & Shock6 & Shock7 & Shock8 & Shock9 \\
\hline 1 & $-4.14 \mathrm{E}-05$ & 2.17E-05 & 0.000531 & 2.97E-05 & 0.464708 & -0.009305 & -0.000868 & $1.16 \mathrm{E}-05$ & $-8.81 \mathrm{E}-06$ \\
\hline 2 & 0.134770 & 0.149541 & 0.037322 & -2.713204 & -0.048016 & -0.055002 & -0.152603 & -0.285498 & 0.127491 \\
\hline 3 & -0.335613 & -0.151998 & 0.219194 & 0.094072 & -0.193044 & -0.254612 & 0.000899 & 1.990718 & -0.226085 \\
\hline 4 & -0.021371 & 0.026332 & 0.041972 & 0.700666 & 0.202418 & -0.222840 & 0.010988 & 0.934970 & -0.057694 \\
\hline 5 & 0.074113 & -0.138190 & 0.080984 & -1.841828 & 0.087780 & -0.001003 & 0.127069 & -1.612711 & 0.042716 \\
\hline 6 & -0.014649 & 0.107646 & -0.212817 & -0.225228 & -0.219122 & 0.399109 & -0.083716 & -0.521786 & -0.006803 \\
\hline 7 & 0.025640 & -0.034064 & -0.091278 & 0.306541 & 0.021127 & -0.021639 & 0.015806 & 2.597086 & -0.001447 \\
\hline 8 & 0.017002 & -0.007116 & -0.110857 & -0.541828 & 0.042706 & -0.014605 & 0.081511 & -1.328246 & 0.002815 \\
\hline 9 & -0.031208 & 0.001666 & 0.200691 & 0.429602 & -0.000380 & -0.094269 & -0.002948 & -0.662061 & -0.048817 \\
\hline 10 & 0.006954 & 0.000296 & -0.104026 & 1.013941 & -0.025174 & 0.054432 & -0.031968 & 0.386031 & 0.060983 \\
\hline
\end{tabular}

Factorization: Structural 
Table 9. Variance decomposition of real output without effects of credit risk

\begin{tabular}{|c|c|c|c|c|c|c|c|c|c|}
\hline \multirow{2}{*}{$\begin{array}{c}\text { Variance } \\
\text { Decomposit } \\
\text { ion of } \\
\text { DLOG(XT_ } \\
\text { D11): }\end{array}$} & \multirow[b]{3}{*}{ S.E. } & \multirow[b]{2}{*}{$\mathrm{mpr}$} & \multirow[b]{2}{*}{$\mathrm{i}$} & \multirow[b]{2}{*}{ er } & \multirow[b]{2}{*}{ ap } & \multirow[b]{2}{*}{$\mathrm{mlr}$} & \multirow[b]{2}{*}{ crs } & \multirow[b]{2}{*}{$\mathrm{m} 2$} & \multirow[b]{2}{*}{$\mathrm{Xt}$} \\
\hline & & & & & & & & & \\
\hline Period & & Shock1 & Shock2 & Shock3 & Shock4 & Shock5 & Shock6 & Shock7 & Shock8 \\
\hline 1 & 0.443392 & $4.83 \mathrm{E}-05$ & $1.28 \mathrm{E}-05$ & 0.011583 & 1.02E-05 & 99.96132 & 0.027012 & $6.62 \mathrm{E}-06$ & $1.10 \mathrm{E}-05$ \\
\hline 2 & 3.336525 & 0.273253 & 0.283984 & 0.008510 & 79.93127 & 1.765407 & 0.070301 & 17.57881 & 0.088472 \\
\hline 3 & 3.565170 & 0.990181 & 0.708051 & 0.080681 & 71.27601 & 1.702675 & 0.326207 & 24.55345 & 0.362749 \\
\hline 4 & 3.923456 & 0.905665 & 0.588378 & 0.135660 & 59.43276 & 1.435174 & 0.427986 & 36.74594 & 0.328435 \\
\hline 5 & 4.460387 & 0.729275 & 0.499721 & 0.133609 & 51.56886 & 1.125669 & 0.354528 & 45.31100 & 0.277339 \\
\hline 6 & 4.623577 & 0.681748 & 0.491128 & 0.125278 & 50.41088 & 1.203016 & 0.730582 & 46.09637 & 0.260996 \\
\hline 7 & 5.332129 & 0.513946 & 0.369275 & 0.120983 & 37.91460 & 0.905216 & 0.551949 & 59.42756 & 0.196471 \\
\hline 8 & 5.339127 & 0.512602 & 0.370066 & 0.135084 & 37.82820 & 0.902848 & 0.553586 & 59.50060 & 0.197012 \\
\hline 9 & 5.417482 & 0.498201 & 0.359491 & 0.149829 & 36.79330 & 0.880710 & 0.540403 & 60.58603 & 0.192035 \\
\hline 10 & 5.506183 & 0.484430 & 0.348353 & 0.152720 & 38.80044 & 0.853109 & 0.523288 & 58.64999 & 0.187668 \\
\hline Average & & 0.558934 & 0.401845 & 0.105393 & 46.39563 & 11.073514 & 0.410584 & 40.84497 & 0.209118 \\
\hline
\end{tabular}

From this study, it is evident that the most effective channels of transmission of monetary policy to the real sector in Nigeria are the credit channel and the asset price channel. This finding is similar to the results of Emenike (2017) and Asaleye, Popoola, Lawal, Ogundipe and Ezenwoke (2018) who found credit channel as the dominant in Nigeria. However, these authors did not consider credit risk in their studies; as a result, they could not establish if their results would remain the same in the period of high credit risk. This study has filled this gap by establishing that during the period of high credit risk in Nigeria, the asset price channel is the most effective channel of transmission of monetary policy to the real sector.

\section{Conclusion}

In the past few years in Nigeria, the real sector has attracted a renewed attention by successive governments. This is in response to the realization of diversifying the economy from oil into deepening the real sector. Monetary policy is one of the major approaches the government has used to improve the sector. Evidence from published circulars by the Central Bank of Nigeria has shown that the monetary authority sometimes finds it challenging to influence the banking system to advance credit to the sector, in response to its monetary policy actions. This sometimes limits the ability of the monetary authority to predictably forecast the reactions of the banking system to its real sector targeted policy. This study therefore investigated the effectiveness of this process vis-à-vis the missing variable that also determines the behavioural lending pattern of the deposit money banks. The transmission channels of monetary policy impulses were also examined. The results of the study established that credit risk is a vital variable that also determines the role of the banking system in channeling credit to the real sector. During the period of high credit risk, the effectiveness of the monetary policy to stimulate the economy is weakened, as banks will prefer to protect their fund to losing it through accumulation of non-performing loans. The results further revealed that asset price channel is the most effective, followed by credit channel, followed by exchange rate channel, while the interest rate channel is the least effective.

\section{Recommendations}

Evidence from the study shows that during the period of high credit risk, activities of credit providers in the banking system may hinder the process of monetary policy transmission, thereby limiting the effectiveness of monetary policy actions to develop the real sector. Therefore, the authors of this study recommend that the monetary authority should always consider the credit preference of the banking system and the order of transmission channels, before embarking on any monetary policy aimed at stimulating any sector of the economy, especially the real sector. 


\section{References}

Adegoriola, A. E. (2018). An empirical analysis of effectiveness of monetary and fiscal policy instruments in stabilizing economy: evidence from Nigeria. Social Sciences, 7(3), $133-140$. https://doi.org/10.11648/j.ss.20180703.14

Adekunle, P. A., Baba N., Yaaba, Stephen, S. A., Ogbuehi, F., Idris, A., \& Zivoshiya, P. B. (2018). Monetary policy transmission in Nigeria: how important is asset prices channel? Microeconomics and Macroeconomics, 6(3), 55-66. https://doi.org/10.5923/j.m2economics.20180603.01

Adeusi, S. O., \& Aluko, O. A. (2015). Relevance of financial sector development on real sector productivity: 21st century evidence from Nigerian industrial sector. International Journal of Academic Research in Business and Social Sciences, 5(6), 118-132.

Ahiawodzi, A. K., \& Sackey, F. G. (2013). Determinants of credit rationing to the private sector in Ghana. African Journal of Business Management, 7(38), 3864-3874. https://doi.org/10.5897/AJBM09.462

Aikman, D., Lehnert, A., Liang, N., \& Modugno, M. (2017). Credit, financial conditions, and monetary policy transmission. Hutchins Center Working Paper \#39. Retrieved from https://www.brookings.edu/research/credit-financial-conditions-and-monetary-policy-transmission

Ajayi, M. A., \& Aluko, O. A. (2017). Evaluating the relative impact of monetary and fiscal policy in nigeria using the St. Louis Equation. Acta Universitatis Danubius. Economica, 13(1), 40-50.

Asaleye, A. J., Popoola, O., Lawal, A. I., Ogundipe, A., \& Ezenwoke, O. (2018). The credit channels of monetary policy transmission: implications on output and employment in Nigeria. Banks and Bank Systems, 13(4), 103-118. https://doi.org/10.21511/bbs.13(4).10

Bernanke, B. S. (1986). Alternative explanations of the money income correlation. Carnegie-Rochester Conference Series on Public Policy, 49-100.

Blanchard, O. J., \& Watson, M. W. (1986). Are Business Cycles All Alike. In R. Gordon (Ed.), The American Business Cycle - Continuity and Change, NBER Studies in Business Cycles (p. 25). Chicago, University of Chicago Press.

CBN. (2019, July 03). Regulatory measures to improve lending to the real sector of the Nigerian economy. BSD/DIR/GEN/MDD/01/045.

CBN. (2019, July 10). Circular to all banks. Re: Guidelines on accessing the CBN standing deposit facility. Ref: FMD/DIR/CON/OGC/12/019.

CBN. (2014, November). Effects of monetary policy on the real economy of Nigeria: a disaggregated analysis.

CBN. (2011). Understanding Monetary Policy Series No. 1.

Claudia, F., \& Massimiliano, M. (2014). Mixed frequency structural VARs. Norges Bank Working Paper, 01. https://doi.org/10.2139/ssrn.2383143

Cooley, T. F., \& Leroy, S. F. (1985). Atheoretical Macroeconometrics. A Critique. Journal of Monetary Economics, 16, 283-308.

Ebire, K., \& Ogunyinka, S. F. (2018). Bank lending channel of monetary policy transmission mechanism in Nigeria. IIARD International Journal of Banking and Finance Research, 4(2), 51-64.

Emenike, K. (2017). How does monetary policy and private sector credit interact in a developing economy?. Intellectual Economics. Retrieved from https://www.researchgate.net/deref/http\%3A\%2F\%2Fdx.doi.org\%2F10.1016\%2Fj.intele.2017.03.001

Erdogdu, A. (2017). Functioning and effectiveness of monetary transmission mechanisms: Turkey applications. Journal of Finance and Bank Management, 5(1), 29-41. https://doi.org/10.15640/jfbm.v5n1a3

Fainstein, G., \& Novikov, I. (2011). The comparative analysis of credit risk determinants in the banking sector of the Baltic States. Review of Economics \& Finance, 1, 20-45.

Falade, O. E., \& Folorunso, B. A. (2015). Fiscal and monetary policy instruments and economic growth sustainability in Nigeria. American Journal of Economics, 5(6), 587-594. https://doi.org/10.5923/j.economics.20150506.04 
Forhad, A. R., Homaifar, G. A., \& Salimullah, A. M. (2017). Monetary policy transmission effect on the real sector of the Bangladesh economy: An svar approach. International Economics, 70(1), 25-46.

Hassan Al-Tamimi, H., \& Mohammed Al-Mazrooei, F. (2007). Banks' risk management: a comparison study of UAE national and foreign banks. Journal of Risk Finance, 8(4), 394-409. https://doi.org/10.1108/15265940710777333

Iortyer, A. D., Imoisi, A., \& Abuh, A. I. (2017). Interest rate behaviour and the Nigerian economy: An error correction mechanism approach. JORIND, 15(1), 185-192. Retrieved from http://www. ajol.info/journals/jorind

Jelilov, G., \& Musa, M. (2016). The impact of government expenditure on economic growth in Nigeria. Sacha Journal of Policy and Strategic Studies, 5(1), 15-23.

Kargi, H. S. (2011). Credit Risk and the Performance of Nigerian banks. Journal of Accounting Research, Department of Accounting, Ahmadu Bello University, Zaria.

Lombardi, D., Siklos, P. L., \& Xie, X. (2018). Monetary policy transmission in systemically important economies and China's impact. CAMA Working Paper, 50.

Mahathanaseth, I., \& Tauer, L. W. (2019). Monetary policy transmission through the bank lending channel in Thailand. Journal of Asian Economics, 60, 14-32.

Mishkin, S. F. (1996). The channels of monetary transmission: lessons for monetary policy. NBER Working Paper, Cambridge, Massachusetts: National Bureau of Economic Research, 5464.

Ndekwu, E. C. (2013). An analysis of the monetary policy transmission mechanism and the real economy in Nigeria. Central Bank of Nigeria occasional papers, 43.

Obafemi, \& Ifere. (2015). Monetary policy transmission mechanism in Nigeria: a FAVAR approach. International Journal of Economics and Finance, 7(8), 229-239. https://doi.org/10.5539/ijef.v7n8p229

Oboh, V. U. (2017). Monetary and Fiscal Policy Coordination in Nigeria: A Set Theoretic Approach. Academic Journal of Economic Studies, 3(1), 48-58.

Ogolo, \& Tamunotonye, M. (2018). Monetary policy and commercial bank lending to the real sector in Nigeria: A time series study. American Finance \& Banking Review, 2(1), 10-41.

Okorie, D. I., Manu, A. S., \& Simon-Peter, D. C. (2017). Relative effectiveness of fiscal and monetary policies in Nigeria. Asian Journal of Social Science Studies, 2(1), 117-121.

Omorokunwa, O. G., \& Adegboye, A. (2011). Monetary policy and bank lending habit in Nigeria. Retrieved from https://www.researchgate.net/publication/308332373

Osundina, K. C., Tella, S. A., \& Adesoye, B. A. (2018). Interest rate channel and real economy in Nigeria: a bayesian vector autoregression approach. International Journal of Economics and Financial Issues, 8(4), 313-321.

Paul, P. (2019). The time-varying effect of monetary policy on asset prices. Federal Reserve Bank of San Francisco Working Paper 2017-09. https://doi.org/10.24148/wp2017-09

Sima, S. (2018). The effect of monetary policy shocks on the real economy: A FAVAR approach. Research Journal of Economics, 2(1), 1-9.

Sims, C. A. (1986). Are forecasting models usable for policy analysis?. Federal Reserve Bank of Minneapolis Quarterly Review, 10(1), 2-16.

Uduak, M. E., \& Obasi, O. U. (2018). Monetary policy pass-through in Nigeria: An ARDL bound testing approach. Atlantic Review of Economics, 1.

\section{Copyrights}

Copyright for this article is retained by the author(s), with first publication rights granted to the journal.

This is an open-access article distributed under the terms and conditions of the Creative Commons Attribution license (http://creativecommons.org/licenses/by/4.0/). 